\title{
LEPTOSPIROSIS IN POLAND IN THE YEARS 2014-2017 - CHARACTERISTICS OF INFECTIONS AND EPIDEMIOLOGICAL SURVEILLANCE DATA
}

\author{
LEPTOSPIROZA W POLSCE W LATACH 2014-2017 - CHARAKTERYSTYKA \\ ZAKAŻEŃ I DANE Z NADZORU
}

\author{
National Institute of Public Health - National Institute of Hygiene \\ Department of Parasitology and Vector-borne Diseases \\ Zakład Parazytologii i Chorób Przenoszonych Przez Wektory \\ NIZP-PZH w Warszawie
}

\begin{abstract}
OBJECTIVES: The aim of the study was the analysis of current Leptospira spp. infections in Poland on the basis of blood serum samples tests results and clinical data collected from clinicians in the Laboratory NIPH-NIH.

METHODS. Clinical materials from 48 patients with clinical symptoms suggesting Leptospira spp suspected of leptospirosis from the years 2014-2017 were included to the study. Blood serum samples collected from patients were tested in Laboratory of Rickettsiae, Chlamydiae and Spirochaetes (currently Laboratory of Vector-borne Diseases) of NIPH-NIH. Levels of specific IgM and IgG antibodies to Leptospira spp. antigens were detected with the enzyme-linked immunosorbent assay (ELISA).

RESULTS. Specific antibodies to Leptospira spp. were detected in 18 patients (37.5\%). IgM antibodies were found in 6 patients $(12.5 \%)$ and IgG antibodies were identified in 7 patients $(14.6 \%)$. Both classes of antibodies of were detected in 5 patients $(10.4 \%)$. The most samples for study were sent to laboratory from Masovian (13 samples) and Kuyavian-Pomeranian (11 samples) Voivodeships. Not any samples from the Lower Silesia, Lublin, Łódź, Podlaskie and Warmian-Masurian Voivodeships were received. In these patients the most common symptoms of disease were: fever, hepatitis with jaundice and renal failure.

CONCLUSIONS. The number of diagnosed human leptospirosis in Poland is low in comparison to the number of cases in other countries, although the Leptospira spp. spirochetes occur in animals in the environment.
\end{abstract}

Key words: Leptospira spp., leptospirosis, infection

\section{STRESZCZENIE}

CEL. Celem prezentowanej pracy jest ocena obecnie występujących w Polsce zakażeń Leptospira spp. na podstawie wyników z badań próbek surowicy krwi, nadesłanych do NIZP-PZH oraz danych klinicznych zebranych od kierujących na badanie lekarzy.

METODY. Badaniami objęto próbki surowicy krwi pochodzące od ludzi chorych z objawami klinicznymi, wskazującymi na zakażenie Leptospira spp., nadesłane do Samodzielnej Pracowni Riketsji, Chlamydii i Krętków Odzwierzęcych (obecnie Pracownia Chorób Przenoszonych przez Wektory) NIZP-PZH, w latach 20142017. Oznaczano poziom swoistych przeciwciał klasy IgM i IgG dla antygenów Leptospira spp. metodą immunoenzymatyczną ELISA.

WYNIKI. W latach 2014-2017 zbadano 48 próbek surowicy krwi pochodzących od osób z klinicznymi objawami wskazującymi na leptospirozę. Swoiste przeciwciała dla Leptospira spp. wykryto u 18 osób (37,5\%). Przeciwciała klasy IgM stwierdzono u 6 osób (12,5\%), przeciwciała klasy IgG wykryto u 7 (14,6\%), a obie klasy przeciwciał wykryto u 5 osób (10,4\%). Najwięcej próbek do badań do Laboratorium NIZP-PZH nadesłano z województwa mazowieckiego (13 próbek) i kujawsko-pomorskiego (11 próbek). Z województwa dolnośląskiego, lubelskiego, łódzkiego, podlaskiego i warmińsko-mazurskiego nie wpłynęła żadna próbka. Objawami dominującymi u pacjentów były: gorączka, zapalenie wątroby i żółtaczka, niewydolność nerek.

(C) National Institute of Public Health - National Institute of Hygiene / Narodowy Instytut Zdrowia Publicznego - Państwowy Zakład Higieny 
WNIOSKI. W Polsce liczba rozpoznawanych zakażeń Leptospira spp. u ludzi jest niewielka w porównaniu z liczbą zakażonych osób w innych krajach, mimo że krętki Leptospira spp. występują u zwierząt na terenie kraju.

Słowa kluczowe: Leptospira spp.,leptospiroza, zakażenia

\section{INTRODUCTION}

Zoonoses are a very serious problem of public health. Infections with microorganisms that cause this group of diseases affect the population in both developing and developed countries.

People who living in adverse conditions, in neglected areas with low hygiene and in close contact with farm animals are mainly exposed to zoonoses. These infections also affect individuals prefering an active and healthy lifestyle, practicing sports, recreation and various forms of tourism, and who often encountering these pathogens directly in the natural environment. Under these circumstances, zoonoses can be transmitting freely and without barriers between animals and humans.

Reservoir of leptospirosis are wild and lived on farms domestic animals. $(1,2,3)$.

Infection, caused by various species of Leptospira, is one of the zoonotic diseases, occurring all over the world, with an estimated 1.03 million annual cases and 58999 deaths $(4,5)$.

The highest incidence and mortality rate are observed in south and south-east Asia, Oceania, Latin America and East Africa (6). Some species of Leptospira are highly pathogenic to humans including Leptospira interrogans, L. kirschneri, L. noguchii, L. alexanderi, L. weilii, L. borgpetersenii, L. santarosai, L. kmetyi.

There are over 300 serovars in the genus Leptospira $(7,8)$. Leptospirosis in humans is most often caused by spirochetes belonging to the serovars: Icterohaemorrhagiae, Grippotyphosa, Pomona, Canicola, Sejroe, Tarassovi. These bacteria are motile, with thin, helically coiled cell, classified as relentless aerobes.

The widespread of particular serovar of the genus Leptospira in a specific geographical region depends on the frequency of occurrence the main host. Infection with pthogens from a specific serovars is associated with definite disease entities, for example Weil's disease is caused by serovar Icterohaemorrhagiae, mud fever is caused by Grippotyphosa and Sejroe serovars, Pomona serovar is responsible for swineherd's disease, and Canicola fever is caused by Canicola (9).

The most common serovars in Europe are $L$. interrogans serovar Copenhageni and $L$. interrogans serovar Icterohaemorrhagiae. In Southern Asia, infections are mainly caused by L. interrogans serovar
WSTĘP

Choroby odzwierzęce to poważny problem zdrowia publicznego. Zakażenia mikroorganizmami powodującymi te choroby dotyczą ludności zarówno w krajach rozwijających się, jak i rozwiniętych.

Grupą osób szczególnie narażonych na choroby odzwierzęce są ludzie żyjący w trudnych warunkach, na terenach zaniedbanych o niskim poziomie higieny, w bliskim kontakcie ze zwierzętami hodowlanymi. Zakażenia te zaczynają dotyczyć także osób prowadzących aktywny i zdrowy tryb życia, uprawiających sporty, rekreację i różne formy turystyki, stykających się $\mathrm{z}$ tymi patogenami bezpośrednio $\mathrm{w}$ środowisku naturalnym. W warunkach tych choroby odzwierzęce swobodnie i bez ograniczeń przenoszą się pomiędzy zwierzętami i ludźmi. Do zakażeń może więc dochodzić zarówno od zwierząt hodowlanych, domowych, jak i dziko żyjących $(1,2,3)$.

Jedną z chorób odzwierzęcych jest leptospiroza, występująca na całym świecie, wywoływana przez różne gatunki krętków z rodzaju Leptospira spp. Bakterie te są ruchliwymi, spiralnie skręconymi i cienkimi krętkami zaliczanymi do bezwzględnych tlenowców. $\mathrm{Na}$ świecie rocznie rejestruje się około miliona zachorowań i 58900 przypadków śmiertelnych będących następstwem leptospirozy $(4,5)$. Najwyższa zapadalność i śmiertelność jest obserwowana w południowej i południowo-wschodniej Azji, Oceanii, Ameryce Łacińskiej i Wschodniej Afryce (6). Niektóre gatunki leptospir są wysoce patogenne dla ludzi (Leptospira interrogans, L. kirschneri, L. noguchii, L. alexanderi, L. weilii, L. borgpetersenii, L. santarosai, L. kmetyi).

W obrębie rodzaju Leptospira jest ponad 300 serowarów $(7,8)$. Leptospirozę u ludzi najczęściej wywołują krętki należące do serowarów: Icterohaemorrhagiae, Grippotyphosa, Pomona, Canicola, Sejroe, Tarassovi. Przewaga w częstości występowania danego serowaru krętków z rodzaju Leptospira w określonym rejonie geograficznym zależy od bytowania głównego gospodarza. Określone serowary są związane z jednostkami chorobowymi np. chorobę Weila wywołuje serowar Icterohaemorrhagiae, gorączkę błotną powodują serowary Grippotyphosa i Sejroe, za chorobę pasterzy świń odpowiedzialny jest serowar Pomona, a przyczyną gorączki canicola jest serowar Canicola (9).

W Europie najczęściej występuje L. interrogans serowaru Copenhageni i Icterohaemorrhagiae. W południowej Azji dominują zakażenia wywoływane 
Lai (8). The most important reservoir of these bacteria are rodents, dogs, cats, pigs, horses, cattle and wild animals. In Poland, pigs, dogs and furry animals such as foxes are more frequently infected $(3,9)$.

Infections with Leptospira spp. in animals occur asymptomatically usually. Spirochetes colonize renal tubules and then can be excreted in large amount in the urine, which leads to contamination of the environment.

Humans and animals leptospirosis are acquired through the contact of damaged skin, mucous membranes, conjunctiva and occasionally through the respiratory tract with water, soil and plants contaminated with infected urine.

The group of people especially exposed to infection due to their professional activity are: butchers, veterinarians, growers (pigs, goats, sheep, cattle), farmers, miners, gardeners, municipal (waste the disposal) employees, fishermen and people associated with water and extreme sports (2).

In humans, leptospirosis usually occurs in two phases. In the early phase, there is a high fever, headache and muscle pain, effusions on the conjunctiva, vomiting, and in the late phase multiorgan damage. The most common symptoms are hepatic dysfunctions manifested by jaundice, acute renal failure, pulmonary haemorrhages, myocarditis, and meningitis and cerebritis, which can lead to death. Sudden appearance of fever and the development of hepato-renal changes during Leptospira spp. infection is described as Weil's disease.

Spirochetes can persist in some organs of the body (in the anterior chamber and the vitreous of the eye and also in the renal tubules) for a long time and they can cause uveitis (months after infection) and leptospiruria (weeks after the disease) $(3,7,9,10)$.

Rare complications in leptospirosis include: cerebrovascular accidents, rhabdomyolysis, thrombotic thrombocytopenic purpura, acute acalculous cholecystitis, erythema nodosum, aortic stenosis, Kawasaki syndrome, reactive arthritis, epididymitis, nerve palsy, male hypogonadism, and Guillain-Barre' syndrome. In pregnant women leptospirosis is carried out as the acute infection, often leading to the death of the fetus or abortion. Also spirochetes were isolated from amniotic fluid, placenta and umbilical cord blood of newborn and visualized them in the liver and kidneys by Warthin-Starry stain. The bacteria are also present in human milk and it is likely to be transmitted by an infected mother breast feeding to the child (3). Acute infections can lead to serious complications and even to death, so it is extremely important to quickly diagnose and initiate appropriate treatment (11-14). Case classification is based on clinical, laboratory and epidemiological criteria. As probable case is considered each patient meeting clinical and przez L. interrogans serowaru Lai. (8) Rezerwuarem tych bakterii są głównie gryzonie, psy, koty, świnie, konie, bydło oraz dzikie zwierzęta. W Polsce częściej zakażone są świnie i psy oraz zwierzęta futerkowe np. lisy, rzadziej bydło $(3,9)$.

Zakażenia krętkami Leptospira spp. u zwierząt przebiegają zwykle bezobjawowo, krętki kolonizują cewki nerkowe i mogą być wydalane w dużej ilości z moczem, co prowadzi do skażenia otoczenia. Do zakażenia u ludzi i zwierząt dochodzi poprzez kontakt z wodą, glebą i roślinami zanieczyszczonymi zakażonym moczem. Krętki wnikają poprzez uszkodzoną skórę, błony śluzowe, spojówki i sporadycznie przez drogi oddechowe.

Grupą osób szczególnie narażonych na zakażenie ze względu na wykonywaną pracę są: pracownicy rzeźni, weterynarze, hodowcy zwierząt (świń, kóz, owiec, bydła), rolnicy, górnicy, ogrodnicy, pracownicy gospodarki komunalnej, rybacy oraz osoby związane ze sportami wodnymi i ekstremalnymi (2).

U ludzi leptospiroza przebiega zwykle dwufazowo. We wczesnej fazie pojawia się wysoka gorączka, ból głowy i mięśni, wybroczyny na spojówkach, wymioty, a następnie dochodzi do uszkodzenia wielu układów (faza późna). Najczęściej są to zaburzenia czynności wątroby objawiające się żółtaczką, ostra niewydolność nerek, liczne krwotoki w płucach, zapalenie mięśnia sercowego oraz zapalenie opon mózgowo-rdzeniowych i mózgu - często kończących się śmiercią chorego. Nagłe pojawienie się gorączki oraz rozwój zmian wątrobowo-nerkowo-płucnych w przebiegu zakażenia krętkami Leptospira spp., opisywane jest jako choroba Weil'a (6).

Krętki potrafią utrzymywać się przez dłuższy czas w organizmie, w komorze przedniej i ciele szklistym oka oraz w kanalikach nerkowych. Obecne w nich krętki wywołują zapalenie błony naczyniowej oka (utrzymujące się miesiące po zakażeniu), oraz leptospirurię (tygodnie po ustąpieniu choroby) $(3,7,9,10)$.

Do bardzo rzadkich powikłań należą: rumień guzowaty, plamica zakrzepowa, rozpad mięśni poprzecznie prążkowanych, zaburzenia naczyniowo-mózgowe, ostre zapalenie pęcherzyka żółciowego, zwężenie zastawki aortalnej, zespół Kawasaki, hipogonadyzm u mężczyzn, zespół Guillain-Barré, reaktywne zapalenie stawów, zapalenie najądrza oraz porażenie nerwów. Leptospiroza u kobiet w ciąży przebiega w postaci ostrej infekcji, która często prowadzi do śmierci płodu i poronienia lub przedwczesnego porodu. W przypadkach tych krętki można wyizolować z łożyska i krwi pępowinowej oraz płynu owodniowego noworodka. Bakterie te są również obecne w ludzkim mleku i prawdopodobnie są przekazywane przez zakażoną matkę dziecku podczas karmienia piersią (3). 
epidemiological criteria, while patients who meet the clinical and laboratory criteria are considered as confirmed cases. (Definition of infectious diseases for epidemiological surveillance (version 3, 2014), Department of Epidemiology, NIPH-NIH).

\section{OBJECTIVE OF THE WORK}

The aim of the presented study is to assessment of Leptospira spp. infections occurring in Poland, based on results from the tests of serum samples, sent to NIPH-NIH and clinical data collected from doctors ordering research. The analysis included the definition of the case of leptospirosis accepted by the WHO and applied by NIPH-NIH for the surveillance.

\section{MATERIALS AND METHODS}

Material for the study included blood serum samples from people with clinical symptoms of Leptospira spp. infection, sent to the Laboratory of Rickettsiae, Chlamydiae and Spirochetes (now the Laboratory of Diseases Transmitted by Vectors) of the National Institute of Public Health - National Institute of Hygiene in the years 2014-2017. These samples came from hospitals from 11 provinces in the country.

Determination of elevated levels of specific IgM antibody to Leptospira spp. is sufficient to confirm the acute phase of disease. Complete serological study includes determination of IgM and IgG classes specific antibodies to Leptospira spp. (15-18).

The levels of specific antibodies of both IgM and IgG classes to Leptospira spp. were determined in all samples with ELISA immunoenzymatic assay using the SERION ELISA classic Leptospira IgM and IgG kits (Institut Virion / Serion GmbH, Germany) according to the manufacturer's instructions. Levels of IgM class of antibodies $\geq 20 \mathrm{U} / \mathrm{ml}$ and $\mathrm{IgG}$ class $\geq 9 \mathrm{U} / \mathrm{ml}$ were considered as a positive.

\section{RESULTS AND DISCUSSION}

Forty eight blood serum samples were collected and examined in 2014-2017 from people with clinical symptoms with suspicion of leptospirosis. These blood samples were taken from 13 women and 35 men. Specific antibodies to Leptospira spp. were detected in 18 patients $(37.5 \%)$. IgM class of antibodies were found in 6 person (12.5\%), IgG antibodies were detected in $7(14.6 \%)$, and both classes of antibodies were detected in 5 individuals $(10.4 \%)$ (Table I).

The most samples for the study were sent to the Laboratory NIPH-NIH from Masovian (13 samples) and Kuyavian-Pomeranian (11 samples). The smallest number of samples were sent to the laboratory from the
Ostre zakażenia mogą prowadzić do poważnych powikłań a nawet śmierci, dlatego niezwykle ważna jest szybka diagnostyka i rozpoczęcie odpowiedniego leczenia (11-14).

Klasyfikacja przypadków oparta jest na kryteriach klinicznych, laboratoryjnych i epidemiologicznych. Za przypadek prawdopodobny uznaje się każdego chorego spełniającego kryteria kliniczne i epidemiologiczne, natomiast za przypadek potwierdzony uznaje się chorych spełniających kryteria kliniczne i laboratoryjne (Definicja przypadku chorób zakaźnych na potrzeby nadzoru epidemiologicznego (wersja 3, 2014 r.), Zakład Epidemiologii Chorób Zakaźnych i Nadzoru NIZP-PZH).

\section{CEL PRACY}

Celem prezentowanej pracy jest ocena obecnie występujących w Polsce zakażeń Leptospira spp. na podstawie wyników z badań próbek surowicy krwi, nadesłanych do NIZP-PZH oraz danych klinicznych zebranych od kierujących na badanie lekarzy. W analizie uwzględniono definicję przypadku leptospirozy przyjętego przez WHO na potrzeby nadzoru i stosowanego przez NIZP-PZH.

\section{MATERIAŁY I METODY}

Materiałem do badań były próbki surowicy krwi pochodzące od ludzi chorych z objawami klinicznymi, wskazującymi na zakażenie Leptospira spp., nadesłane do Samodzielnej Pracowni Riketsji, Chlamydii i Krętków Odzwierzęcych (obecnie Pracownia Chorób Przenoszonych przez Wektory) Narodowego Instytutu Zdrowia Publicznego-Państwowego Zakładu Higieny, w latach 2014-2017. Próbki pochodziły ze szpitali z 11 województw na terenie kraju.

Do potwierdzenia ostrej fazy leptospirozy wystarczające jest oznaczenie przeciwciał klasy IgM dla Leptospira spp., natomiast pełne badanie serologiczne obejmuje oznaczenie przeciwciał klasy IgM i IgG dla Leptospira spp. (15-18).

W próbkach oznaczano poziom swoistych przeciwciał obu klas: IgM i IgG dla antygenów Leptospira spp. metodą immunoenzymatyczną ELISA, stosując zestawy SERION ELISA classic Leptospira IgM i IgG (Institut Virion/Serion GmbH, Niemcy), zgodnie z instrukcją producenta. Poziomy przeciwciał klasy IgM $\geq 20 \mathrm{U} / \mathrm{ml}$ i klasy $\mathrm{IgG} \geq 9 \mathrm{U} / \mathrm{ml}$ przyjmowano jako wynik dodatni.

\section{WYNIKI I ICH OMÓWIENIE}

Zbadano 48 próbek surowicy krwi nadesłanych w latach 2014-2017, od osób z klinicznymi objawa- 
Pomerania and Świętokrzyskie provinces (1 sample) (Fig. 1). There was no sample from the Lower Silesia, Lubelskie, Lodzkie, Podlaskie and Warmian-Masurian Voivodships. mi wskazującymi na leptospirozę. Próbki krwi pobrano od 13 kobiet i 35 mężczyzn. Swoiste przeciwciała dla Leptospira spp. wykryto u 18 osób (37,5\%). Przeciwciała klasy IgM stwierdzono u 6 osób (12,5\%), przeciwciała klasy IgG wykryto u 7 (14,6\%), a obie klasy przeciwciał wykryto u 5 osób $(10,4 \%)$ (Tab. I).

Table. I. The occurrence of specific antibodies to Leptospira spp. in patients with clinical symptoms of leptospirosis Tabela. I. Występowanie przeciwciał swoistych dla Leptospira spp. u osób z klinicznymi objawami leptospirozy

\begin{tabular}{|c|c|c|c|c|}
\hline \multirow[t]{2}{*}{ Year of recognition } & \multirow[t]{2}{*}{ Number of examined patients } & \multicolumn{3}{|c|}{$\begin{array}{c}\text { Number }(\%) \text { of patients with antibodies } \\
\text { to Leptospira spp. antigens }\end{array}$} \\
\hline & & IgM & IgG & IgM+IgG \\
\hline 2014 & 4 & 0 & 1 & 2 \\
\hline 2015 & 11 & 1 & 3 & 0 \\
\hline 2016 & 12 & 2 & 0 & 0 \\
\hline 2017 & 21 & 3 & 3 & 3 \\
\hline TOTAL & 48 & $6(12.5)$ & $7(14.6)$ & $5(10.4)$ \\
\hline
\end{tabular}

* patients with both positive and borderline results

*osoby z wynikami dodatnimi i wątpliwie-dodatnimi

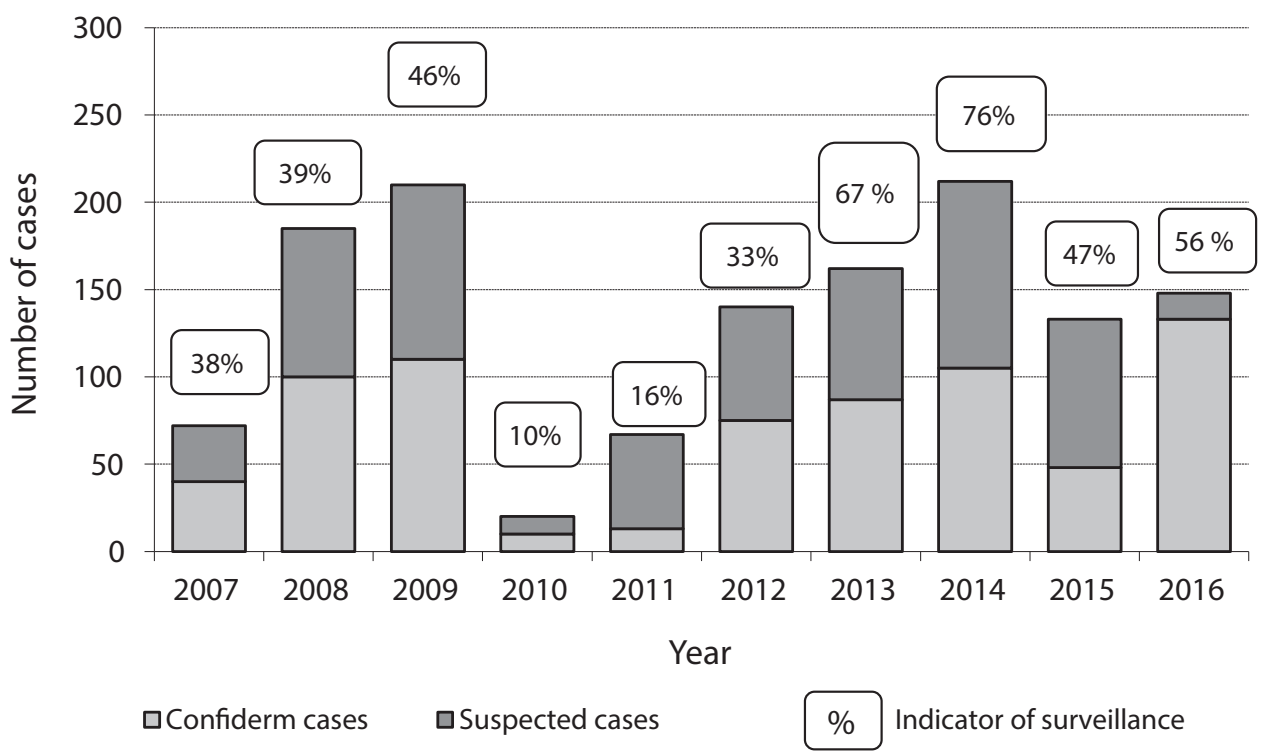

Fig. 1. The occurrence of antibodies to Leptospira spp. in humans, in the 2014-2017 by voivodships, in Poland Ryc. 1. Występowanie przeciwciał dla Leptospira spp. u ludzi w Polsce w latach 2014-2017 wg województw

Analysis of the received results indicates that persons aged between 11 and 40 are most often infected group of patients (Fig. 2). The main symptoms were as follows: fever, hepatitis and jaundice, also renal failure (Tab. II).

Currently, a case of leptospirosis in Poland must be reported and registered. According to epidemiological data of the Department of Epidemiology NIPH-NIH, the number of reported cases in the years 2014-2017 were 53. This number seems to be underestimated, because there are voivodships in which tests on leptospirosis are not performed but studies of the reservoir prove that animals infected with Leptospira spp. occurred.
Najwięcej próbek do badań do Laboratorium NIZP-PZH nadesłano z województwa mazowieckiego (13 próbek) i kujawsko-pomorskiego (11 próbek).

Najmniej próbek przesłano do laboratorium z województwa pomorskiego, świętokrzyskiego (po 1 próbce) (Ryc. 1). Z województwa dolnośląskiego, lubelskiego, łódzkiego, podlaskiego i warmińsko-mazurskiego nie wpłynęła żadna próbka.

Analiza wyników przeprowadzonych badań wskazuje, że najczęściej chorują osoby w wieku od 11 do 40 roku życia (Ryc. 2). Objawami dominującymi u pacjentów były: gorączka, zapalenie wątroby i żółtaczka, niewydolność nerek (Tab. II). 
Table. II. Clinical symptoms observed in leptospirosis cases confirmed with serological tests

Tabela. II. Charakterystyka objawów klinicznych u pacjentów z leptospirozą potwierdzoną badaniami serologicznymi

\begin{tabular}{|l|c|}
\hline \multicolumn{1}{|c|}{ Characteristic } & Patients with antibodies to leptospirosis (n=18) \\
\hline Number of men / women & $11 / 7$ \\
\hline Periods of the most frequent cases: & $6 / 18$ \\
June-September & $7 / 18$ \\
October-January & $5 / 18$ \\
February-May & \\
\hline Main symptoms: & $7 / 18$ \\
Fever & $2 / 18$ \\
Pain of muscle, head and stomach & $1 / 18$ \\
Nausea & $2 / 18$ \\
Bacteraemia & $5 / 18$ \\
Hepatitis & $5 / 18$ \\
Jaundice & $5 / 18$ \\
Kidney failure & $1 / 18$ \\
Meningitis and encephalitis & \\
\hline
\end{tabular}
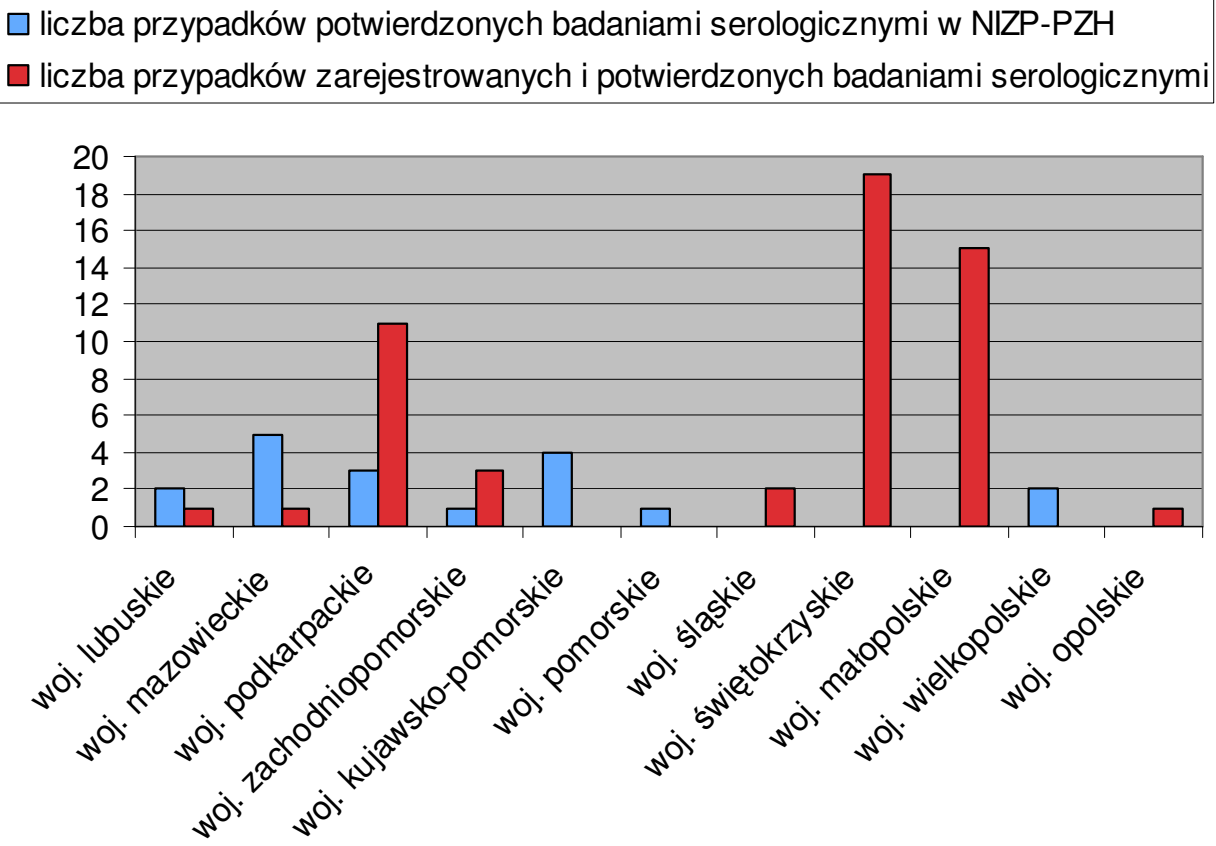

Fig. 1. Measles surveillance performance in Poland 2007-2016.

Ryc. 1. Sprawność nadzoru epidemiologicznego nad odrą w Polsce w latach 2007-2016.

In 2006, 7252 blood sera collected from pigs from 12 provinces were examined. Antibodies to Leptospira spp. were detected in $97(1.34 \%)$ animals. In the same year, only 6 cases of leptospirosis were registered in Poland, and 5 of them occurred in the following provinces: Kuyavian-Pomeranian (2), Masovia (2) and Greater Poland (1), where infected pigs were found (19, $20)$. In the same study in $2006,1,95 \%$ of pigs infected with Leptospira spp. were detected in the Lower Silesia Voivodship, $1,36 \%$ in the Lubelskie, $0,28 \%$ in the Lodzkie, $0,32 \%$ in the Podlaskie Voivodship and 1, $97 \%$ in the Warmian-Masurian Voivodship.

In 2010, in the same voivodships the presence of Leptospira spp. antibodies in examinated pigs, were detected respectively in $1,37 \%$ in the Lower Silesia,
Obecnie w Polsce leptospiroza podlega obowiązkowi zgłoszenia i rejestracji. Według danych epidemiologicznych Zakładu Epidemiologii Chorób Zakaźnych i Nadzoru NIZP-PZH, ilość zgłoszonych przypadków w latach 2014-2017 wyniosła 53. Liczba ta wydaje się być niedoszacowana, ponieważ są województwa, w których nie wykonuje się testów w kierunku leptospirozy a badania rezerwuaru dowodzą, że występują na tych terenach zwierzęta zakażone krętkami Leptospira spp.

W 2006 roku zbadano 7252 surowice pobrane od świń z 12 województw. Przeciwciała dla Leptospira spp. wykryto u 97 (1.34\%) zwierząt. W tym samym 2006 roku na terenie Polski zarejestrowano tylko 6 przypadków zachorowań na leptospirozę, a $5 \mathrm{z}$ nich 
$0,86 \%$ in the Lubelskie, $0,54 \%$ in the Lodzkie, $1,04 \%$ in the Podlaskie and $1,09 \%$ in the Warmian-Masurian voivodships (21).

In the years 2014-2017, no cases of human disease were reported from these voivodships, although, in the previous years the percentage of infected pigs remained at a similar level according to the above studies. This may indicate that either cases of people with leptospirosis are incorrectly diagnosed and therefore they are not examined in these voivodeships or the cases are not reported.

Studies carried out among wild and free range animals indicate that Leptospira spp. spirochetes still are found in the environment and can cause infection. Serological tests in wild boars in Poland showed that $25 \%$ of tested animals had a high level of antibodies against Leptospira spp..

Positive serological reactions were also found in $3,4 \%$ of examined sheep and in $3,2 \%$ of 309 milk samples collected from cows from the south-western regions of Poland (22-24). Increase in the number of cases of leptospirosis in humans and animals is often associated with the occurrence of natural disasters. In 1997, during the floods in Poland, increase of Leptospira spp. infections in humans were occurred. Similarly, increase in the cases of leptospirosis among animals was also observed. Such studies were carried out in the Lublin region, where 32 sera from 41 animals, 41 sera from cows, 30 samples from organs (kidneys and liver) of small mammals (Apodemus agrariusz, Apodemus flavicollis, Apodemus sylvaticus, Microtus agrestis, Microtus arvalis, Myodes glareolus, Sorex araneus) 40 water samples, 40 soil samples and 540 Ixodes ricinus ticks were collected from flooded areas. At the same time, a similar number of samples for research were collected and examined from areas of this province but not affected by floods. Then $34,4 \%$ of pigs, $26 \%$ of cows from the floodplains had antibodies to Leptospira spp., compared to $4,9 \%$ of pigs and $15,0 \%$ of cows from "dry" areas. DNA of Leptospira spp. was detected in $20 \%$ of small mammals, $15,6 \%$ of ticks and in $5 \%$ of water samples. For comparison, in areas where there was no flood, DNA Leptospira spp. was detected in $30 \%$ of small mammals and $1,4 \%$ of ticks. Water samples in this area and soil in both areas were negative. These studies show that the most important for dissemination of Leptospira spp. infection seems to be ticks, farm animals, mice and contaminated water (25-27).

Based on epidemiological reports of the Department of Epidemiology NIPH-NIH, the number of leptospirosis cases varies from 2 cases in 2017, 3 cases in 2003, to 12 cases in 2000 and 2007 in Poland. In the years 1996-2017, two significant increases in the incidence of leptospirosis were observed. The first występowało na terenach województw: Kujawsko-Pomorskiego (2), Małopolskiego (2) i Wielkopolskiego (1), na których stwierdzono zakażone świnie $(19,20)$.

W tym samym badaniu 2006 roku w województwie dolnośląskim występowało 1,95\% zakażonych krętkami Leptospira spp. świń, w województwie lubelskim $1,36 \%$, w województwie łódzkim $0,28 \%$, w województwie podlaskim $0,32 \%$ a w województwie warmińsko-mazurskim 1,97\%. W 2010 roku obecność przeciwciał dla Leptospira spp. w tych samych województwach wynosiła odpowiednio: w województwie dolnośląskim 1,37\%, w województwie lubelskim $0,86 \%$, w województwie łódzkim $0,54 \%$, w województwie podlaskim $1,04 \%$ a w województwie warmińsko-mazurskim 1,09\% badanych świń (21).

W latach 2014-2017 z tych województw nie zgłoszono żadnego przypadku zachorowania u ludzi, mimo że jak wynika z powyższych badań, w poprzednich latach odsetek zakażonych świń utrzymywał się na podobnym poziomie. Może to świadczyć o tym, że albo przypadki osób chorych na leptospirozę są nieprawidłowo rozpoznawane i w związku z tym nie są one badane w tych województwach, albo nie są zgłaszane.

Badania prowadzone wśród zwierząt dziko żyjących i z wolnego wybiegu wskazują, że krętki Leptospira spp. stale występują także w środowisku, mogąc wywoływać zakażenia. Badania serologiczne na dzikach w Polsce wykazały, że 25\% zbadanych dzików miało wysoki poziom przeciwciał przeciw Leptospira spp. Dodatnie odczyny serologiczne stwierdzono także u 3,4\% zbadanych owiec, natomiast w 309 próbkach mleka krowiego, pochodzących $\mathrm{z}$ południowo-zachodnich regionów Polski obecność przeciwciał dla Leptospira spp. stwierdzono u 3,2\%. (22-24).

Nagły wzrost liczby zachorowań na leptospirozę u ludzi i zwierząt jest często związany z wystąpieniem klęsk żywiołowych. Taki wzrost stwierdzono w 1997 roku, w czasie powodzi w Polsce. Zaobserwowano także wzrost liczby zakażeń wśród zwierząt. Badania takie przeprowadzono na terenie Lubelszczyzny, gdzie zebrano 32 surowice krwi od świń, 41 surowic od krów, 30 próbek organów (nerki i wątroby) drobnych ssaków (myszarka polna, myszarka leśna i zaroślowa, nornik pospolity i bury, nornica ruda, ryjówka aksamitna), 40 próbek wody i 40 próbek gleby oraz 540 kleszczy Ixodes ricinus z obszarów zalewanych przez powodzie. Jednocześnie podobną liczbę próbek do badań zebrano i zbadano z obszarów województwa niedotkniętych powodziami. 34,4\% świń, $26 \%$ krów z terenów zalewowych miało przeciwciała dla Leptospira spp. w porównaniu do 4,9\% świń i 15,0\% krów z terenów „suchych”. DNA Leptospira spp. wykryto u $20 \%$ drobnych ssaków i 15,6\% kleszczy oraz w 5\% próbek wody. 
increase of leptospirosis took place in 1997, when the flood occurred (mentioned above). Then 21 cases were recorded at that time (incidence 0.05 per 100,000 population), what was a big increase compared to the below 10 usual cases. Of these 21 cases, 12 cases occurred in flooded areas. Another increase in human cases occurred in 2014 and amounted 25 cases (incidence 0.06 per 100,000 population). It was triggered by outbreak of leptospirosis associated with seasonal work (strawberry harvest) in Germany. At that time people from various areas of Poland were infected. Ten people with symptoms of leptospirosis after being on a strawberry plantation were examined in the Laboratory of Rickettsia, Chlamydia and Spirochetes of NIPH-NIH. In six persons (60\%) a high level of antibodies to Leptospira spp. by ELISA test was detected. In 2 of 6 persons high titres were obtained using the MAT test (microscopic agglutination test). At the same time, another 4 people from Poland were hospitalized in Germany because due to clinical symptoms of Weil's disease $(26,28)$. The small number of confirmed leptospirosis cases are caused improperly collected material for tests or inadequate time of sampling. Low detection by laboratories it is also arise by the fact that often the tests are carried out once, and it is impossible to determine the dynamics of antibodies.

The basic method used in laboratories to diagnose these infection it is the ELISA test, which determined the IgM and IgG classes of specific antibodies for the spirochetes Leptospira spp. in blood serum. The presence of IgM class antibodies can be detected already about 4-5 days after the onset of symptoms and it can persist for several months. IgG class antibodies appear around the 7 day of the onset of symptoms and may be detectable in the blood serum for several years (up to 6 years after infection). Due to the fact that blood culture and the microscopic agglutination test (MAT) are laborious and required time, they are rarely used in diagnosis $(17,18,29)$.

A very sensitive method used during the acute phase of infection is PCR or Real-Time PCR. This test could be done using the patient's blood, urine and tissues. Sequences of the most often applied primers in this molecular method is complementary to the genes: lipL32, $1 \mathrm{fb} 1$ (only present in pathogenic species) or characteristic for the whole genotype: rrs (16S rRNA), secY, gyrB (genes of basic metabolism) $(30,31)$. The DNA of spirochetes Leptospira spp. can be detected in the blood only during the first week of the disease in untreated patients.

In the next, later phase, DNA of these spirochetes can be detected only in the urine, but incorrect preparation of this samples after collection often lead to a false negative results. Bacteria of the genus
Dla porównania, na obszarach gdzie nie było powodzi, DNA Leptospira spp. wykryto u 30\% drobnych ssaków i 1,4\% kleszczy. Próbki wody na tym terenie i gleby na obu obszarach były ujemne. $Z$ badań tych wynika, że najistotniejsze w szerzeniu zakażenia Leptospira spp. wydają się być kleszcze, zwierzęta hodowlane, myszy polne oraz skażona woda (25-27).

$\mathrm{Na}$ podstawie meldunków epidemiologicznych Zakładu Epidemiologii Chorób Zakaźnych i Nadzoru NIZP-PZH, w Polsce liczba zachorowań na leptospirozę ludzi waha się od 2 przypadków w 2017, 3 przypadków w 2003 roku, do 12 przypadków w 2000 i 2007 roku. W latach 1996-2017, zaobserwowano dwa znaczące wzrosty liczby zachorowań na leptospirozę. Pierwszy wzrost zachorowań, jak już wspomniano powyżej, miał miejsce w 1997 roku, kiedy to miała miejsce powódź. Zarejestrowano wówczas 21 przypadków zachorowań (zapadalność 0,05 na 100 tys. ludności), co w stosunku do poniżej 10 zwykle występujących przypadków jest dużym wzrostem. $Z$ tych 21 przypadków zachorowań aż 12 przypadków występowało na terenach objętych powodzią. Kolejny wzrost zachorowań przypadł na 2014 rok i wynosił 25 przypadków (zapadalność 0,06 na 100 tys. ludności). Wynikało to z wystąpienia ogniska leptospirozy związanego z pracami sezonowymi (zbiorami truskawek) na terenie Niemiec, gdzie doszło w tym czasie do zakażenia osób z różnych terenów Polski. Dziesięć osób z objawami leptospirozy po pobycie na plantacji truskawek było badanych w Samodzielnej Pracowni Riketsji, Chlamydii i Krętków Odzwierzęcych NIZP-PZH. U 6 osób $(60 \%)$ wykryto metodą ELISA wysoki poziom przeciwciał dla Leptospira spp. U 2 z 6 uzyskano wysokie miana przy zastosowaniu testu MAT (microscopic agglutination test). W tym samym czasie kolejne 4 osoby z Polski były hospitalizowane w Niemczech ze względu na występowanie u nich objawów choroby Weil'a $(26,28)$.

Przyczyną małej liczby potwierdzonych zgłoszeń leptospirozy, jest nieprawidłowo pobrany materiał do badań lub nieodpowiedni czas. Niska wykrywalność przez laboratoria wynika też z faktu, że często badanie wykonywane jest jednorazowo, co nie daje możliwości stwierdzenia dynamiki przeciwciał.

Podstawową metodą diagnostyczną tych zakażeń stosowaną w laboratoriach jest test ELISA, którym oznacza się swoiste przeciwciała klasy IgM i IgG dla krętków Leptospira spp. w surowicy krwi. Obecność przeciwciał klasy IgM można wykryć już ok. 4-5 dnia od wystąpienia objawów. Mogą one się utrzymywać przez kilka miesięcy. Przeciwciała klasy IgG pojawiają się ok.7 dnia od wystąpienia objawów i mogą być obecne w surowicy krwi przez kilka lat (nawet do 6 lat po zakażeniu). Ze względu na to, że posiew krwi oraz test mikroskopowej aglutynacji (MAT) są pracochłonne i wymagają czasu, obecnie są rzadko wykonywane $(17,18,29)$. 
Leptospira are very susceptible for acidic environment (pH below 6,8) and after 90 minutes in contact with acid urine, the spirochetes are not detectable with PCR $(32,33,34)$.

According to procedures described in scientific studies, the collected urine should be centrifuged several times, and the sediment should be rinsed with PBS buffer (sodium chloride buffered with phosphates $\mathrm{pH}$ 7.2) and also sterile distilled water. In the last stage, the sediment should be incubated for $10 \mathrm{~min}$ at $100^{\circ} \mathrm{C}$ and thus prepared used in the diagnose or frozen at $-20^{\circ} \mathrm{C}$ sent to the laboratory.

\section{SUMMARY AND CONCLUSION}

1. In Poland, the number of diagnosed Leptospira spp. infections in humans is small compared to the number of infected people in other countries.

2. In connection to the occurrence of spirochetes Leptospira spp. in animals, it can be assumed that infections with these pathogens in humans are more frequent than reported in Poland.

3. In some provinces, leptospirosis is not diagnosed.

\section{PIŚMIENNICTWO}

1. Baharti AR, Nally JE, Ricaldi JN, et al. Leptospirosis: a zoonotic disease of global importance. Lancet Infect Dis 2003;3:757-771.

2. Vasylieva N, Andreychyn M, Kravchuk Y, et al. Changes in leptospirosis etiology in animals and humans. Ann Agric Environ Med. 2017;24:671675.

3. Levett PN. Leptospirosis. Clin Microbiol Rev 2001;14:296-326.

4. Costa F, Hagan JE, Calcagno J, et al. Global Morbidity and Mortality of Leptospirosis: A Systematic Review. PLoS Negl Trop Dis. 2015;9:e0003898.

5. Naotunna C, Agampodi SB, Agampodi TC. Etiological agents causing leptospirosis in Sri Lanka: A review. Asian Pac J Trop Med. 2016;9:390-394.

6. Evangelista KV, Coburn J. Leptospira as an emerging pathogen: a review of its biology, pathogenesis and host immune responses. Future Microbiol 2010;5:1413-1425.

7. Guernier V, Allan KJ, Goarant C. Advances and challenges in barcoding pathogenic and environmental Leptospira. Parasitology. 2018;145:595-607.

8. Cantas L, Suer K. Review: the important bacterial zoonoses in "one health" concept. Front Public Health 2014; 2:144.
Bardzo czułą metodą, stosowaną w okresie ostrej fazy zakażenia jest metoda PCR lub Real-Time PCR. Badanie to wykonuje się z krwi, moczu i tkanek chorego. Starterami najczęściej stosowanymi są sekwencje komplementarne do genów: lipL32, lfb1 (występują tylko u patogennych gatunków) lub charakterystycznych dla całego gatunku genów: rrs (16S rRNA), secY, gyrB (geny metabolizmu podstawowego) $(30,31)$. DNA krętków Leptospira spp. można wykryć we krwi tylko w ciągu pierwszego tygodnia choroby. W późniejszej fazie, DNA tych krętków można wykrywać tylko w moczu jednak nieprawidłowe opracowanie próbki po pobraniu skutkuje często wynikiem fałszywie ujemnym. Bakterie z rodzaju Leptospira są wrażliwe na kwaśne środowisko (pH poniżej 6.8) i już po 90 min kontakcie z kwaśnym moczem, nie są wykrywalne metodą PCR $(32,33,34)$. Zgodnie z licznymi opracowaniami naukowymi, pobrany mocz powinien być kilkakrotnie zwirowany, a osad przepłukiwany buforem PBS (chlorek sodu buforowany fosforanami $\mathrm{o} \mathrm{pH} \mathrm{7,2)} \mathrm{oraz} \mathrm{sterylną} \mathrm{wodą} \mathrm{destylowaną.} \mathrm{W} \mathrm{ostatnim}$ etapie osad powinien być inkubowany przez $10 \mathrm{~min}$ w $100{ }^{\circ} \mathrm{C}$ i tak przygotowany przesłany do laboratorium lub zamrożony $\mathrm{w}-20^{\circ} \mathrm{C}$.

\section{WNIOSKI}

1. W Polsce liczba rozpoznawanych zakażeń Leptospira spp. u ludzi jest niewielka w porównaniu z liczbą zakażonych osób w innych krajach.

2. W związku z występowaniem krętków Leptospira spp. u zwierząt na terenie Polski, można przypuszczać, że zakażenia tymi patogenami u ludzi występują częściej niż jest to zgłaszane.

3. W niektórych województwach, leptospiroza nie jest diagnozowana.

9. Gliński Z, Kostro K. Leptospiroza - groźna choroba zwierząt i zoonoza. Życie Weter 2013; 88: 835-841.

10. Hazaei C. Pathogenic Leptospira: Advances in understanding the molecularpathogenesis and virulence. Open Vet J 2018;8:13-24.

11. Schwartz DA. Emerging and reemerging infections. Progress and challenges in the subspecialty of infectious disease pathology. Arch Pathol Lab Med 1997;121:776-784.

12. Emond R, Rowland HAK, Welsby P. Atlas chorób zakaźnych.. Warszawa: Springer PWN;1996

13. Jaworska M, Bentkowski W. Leptospiroza, jako przyczyna ostrego uszkodzenia nerek - opis dwóch przypadków klinicznych i przegląd piśmiennictwa. Nefrologia i Dializoterapia Polska. 2015; 3:136-139. 
14. Stobart Gallagher MA, Dunn N. Leptospirosis (Weil Disease). Treasure Island (FL): StatPearls Publishing; 2018. http://www.ncbi.nlm.nih.gov/ books/NBK441858/

15. Musso D, La Scola B. Laboratory diagnosis of leptospirosis: a challenge. J Microbiol Immunol Infect 2013;46(4):245-252.

16. Ooteman MC, Vago AR, Koury MC. Evaluation of MAT, IgM ELISA and PCR methods for the diagnosis of human leptospirosis. J Microbiol Methods 2006;65:247-257.

17. Trombert-Paolantoni S, Thomas P, Hermet F, et al. Leptospirosis screening: performance of the Serion Elisa Classic Leptospira IgM KIT. Pathol Biol 2010;58:95-99.

18. Rosa MI, Reis MFD, Simon C, et al. IgM ELISA for leptospirosis diagnosis: a systematic review and meta-analysis. Cien Saude Colet 2017;22(12):4001-4012.

19. Wasiński B. Occurrence of Leptospira spp. antibodies in swine in Poland. Bull Vet Inst Pulawy 2007;51:225-228.

20. PZH, Instytut Naukowo-Badawczy-Zakład Epidemiologii, GIS-Departament Przeciwepidemiologiczny. Choroby zakaźne i zatrucia w Polsce. 2006.

21. Wasiński B, Pejsak Z. Occurrence of leptospiral infections in swine population in Poland evaluated by ELISA and microscopic agglutination test. Pol J Vet Sci 2010;13(4):695-699.

22. Rypuła K, Płoneczka-Janeczko K, Bierowiec K, et al. Prevalence of antibodies to Leptospira hardjo in bulk tank milk from unvaccinated dairy herds in the south-west region of Poland. Berl Munch Tierarztl Wochenschr. 2014;127(5-6):247-250.

23. Krawczyk M. Leptospiroza owiec na podstawie badań serologicznych. Med Weter 1999;55:397399.

24. Wasiński B. Leptospirosis--current problems. Przegl Epidemiol. 2011;65(3):471-476.

25. Wójcik-Fatla A, Zając V, Sroka J, et al. A small scale survey of Leptospira in mammals from eastern Poland. Ann Agric Environ Med 2013;20(4):705707.

26. Dutkiewicz J, Wójcik-Fatla A, Zając V, et al. Ocena narażenia populacji wiejskiej Lubelszczyzny na zakażenie Krętkami z rodzaju Leptospira, ze szczególnym uwzględnieniem terenów popowodziowych. Medycyna Ogólna i Nauki o Zdrowiu 2015; 21(1):65-70.
27. Wójcik-Fatla A, Zając V, Cisak E, et al. Leptospirosis as a tick-borne disease? Detection of Leptospira spp. in Ixodes ricinus ticks in eastern Poland. Ann Agric Environ Med 2012;19(4):656659.

28. Fiecek B, Chmielewski T, Sadkowska-Todys $\mathrm{M}$, et al. An outbreak of leptospirosis imported from Germany to Poland. Adv Clin Exp Med 2017;26(3):415-419.

29. Marquez A, Djelouadji Z, Lattard V, et al. Overview of laboratory methods to diagnose Leptospirosis and to identify and to type leptospires. Int Microbiol 2017;20(4):184-193.

30. Mérien F, Amouriaux P, Perolat P, Baranton G, Saint Girons I. Polymerase chain reaction for detection of Leptospira spp. in clinical samples. J Clin Microbiol 1992;30(9):2219-2224.

31. Waggoner JJ, Pinsky BA. Molecular diagnostics for human leptospirosis. Curr Opin Infect Dis 2016;29(5):440-445.

32. Lucchesi PM, Arroyo GH, Etcheverría AI, et al. Recommendations for the detection of Leptospira in urine by PCR. Rev Soc Bras Med Trop 2004;37(2):131-134.

33. Hamond C, Martins G, Loureiro AP, et al. Urinary PCR as an increasingly useful tool for an accurate diagnosis of leptospirosis in livestock. Vet Res Commun 2014;38(1):81-85.

34. Gerritsen MJ, Olyhoek T, Smits MA, Bokhout BA. Sample preparation method for polymerase chain reaction-based semiquantitative detection of Leptospira interrogans serovar Hardjo subtype Hardjobovis in bovine urine. J Clin Microbiol 1991;29(12):2805-8

Received: 17.05.2018

Accepted for publication: 2.07.2018

Otrzymano: $17.05 .2018 \mathrm{r}$.

Zaakceptowano do publikacji: $2.07 .2018 \mathrm{r}$.

Adres do korespondencji:

Address for correspondence:

Beata Fiecek

Zakład Parazytologii i Chorób Przenoszonych

przez Wektory

Narodowy Instytut Zdrowia Publicznego-Państwowy

Zakład Higieny

ul. Chocimska 24

00-791 Warszawa, Polska

Telefon: 225421261

e-mail: bfiecek@pzh.gov.pl 